\title{
Application of Conservation Techniques in the Potato Planting Area in Jeneberang Watershed
}

\author{
Marupah $^{1}$, Hazairin Zubair ${ }^{2}$, Sumbangan Baja ${ }^{3}$, Didi Rukmana ${ }^{4}$ \\ ${ }^{1} \mathrm{PhD}$ Candidate of Agricultural Science, Postgraduate School, University of Hasanuddin \\ ${ }^{2,3,4}$ Lecturer at the Postgraduate School of the University of Hasanuddin
}

\begin{abstract}
Potato plants grow well on a highland with an altitude above $1000 \mathrm{~m}$ above sea level. Low potato productivity achieved by farmers isdue to less than optimalcrop cultivation technique used. Land management on the highland with steep slopes generally do not implement appropriate soil and water conservation techniques causing land degradation due to erosion. This study aims to measure the rate of erosion and potato production in various cropping models or soil conservation techniques in the Jeneberang watershed. Four models of cropping were applied namely 1. Planting in the direction of the slopes which generally applied by local farmers in the study area; 2. Planting across the slopes; 3.Planting across the slopes with seedbeds of plant; 4.Planting across the slopes with trench in every 5 meters. Erosion rate measurement was carried out by creating erosion plot with a length of 22 meters and a width of 4 meters. The results show that the cropping model using conservation techniques had highly significant effect on the erosion rate. The highest erosion rates indicated by the model of planting in the direction of slope (model applied by the potato farmers) compared to other models of planting. Potato production was highest when planted using contour farming with two lanes of plant beds.
\end{abstract}

Keywords: erosion rate, cropping patterns, potatoes, watershed, slopes

\section{Introduction}

Erosion is the loss or process of eroding of soil or parts of the ground in an area by the action of water or wind (Arsyad, 2010). Surface erosion can occur begins with the destruction of soil aggregate by rainwater collision on the ground surface that has greater energy than the durability of the ground. Soil particles disclosed from the surface will cause blockage of the pores of the upper soil making soil infiltration capacity declinesand water runoff increases. Increased surface water runoff that occurs has a scraper energy and transport soil particles (Seta, 1987). The impact caused by surface erosion, especially the type of accelerated erosion,are: (a) the decline of soil productivity and the carrying capacity of the environment on the erodedland (b) the silting of rivers, reservoirs and irrigation channels in the lower regions reducing their usefulness and useful life (c) indirectly result in chronic flooding during the rainy seasonand dry during drought periods (Arsyad, 2010).

Erosion is a major problem in the watershed of Jeneberang. Previous studies indicate that the erosion in the thiswatershed was so severe that has led to degradation and unproductive land. The critical land in the Jeneberangwatershed cover an area of 53471 ha and tended to increase (BP DAS Jeneberang Walanae, 2003 in Saida, 2011).Soil conditions that are vulnerable to erosion, topography of the area which is generally sideways until very oblique and high intensity rainfall causes erosion rate is very high. Therefore, land productivity in this area has declined.

The watershed of Jeneberang, located in Gowaregency, is one of the centers of horticultural cropsconsiderable potential in South Sulawesi province, but the productivity of both quality and quantity are still relatively low compared to the other regions. The productivity of potato in South Sulawesi in 2009 was 8.24 tonnes / ha, cabbage 16.79 tonnes
/ ha, carrot 8.68 tonnes / ha, and scallion 5.70 tonnes / ha, while the productivity of potato in West Java reached 20.89 ton / ha and scallion 13.84 tonnes / ha, cabbage in West Sumatra reached 31.39 tons / ha, carrot in North Sumatra reached 21.20 tonnes / ha (BPS, 2010).

Horticulture region in the highlands is generally located in the headwater area of the watershed. Approximately $46 \%$ of its territory is hilly with slopes of more than $15 \%$ which is very vulnerable to hazards such erosion. Land with this type of slopes are scattered on the higland with an altitude of $\geq 700 \mathrm{~m}$ above sea level (Hidayat and Mulyani, 2005). This area is very important as a producer of agricultural commodities, especially vegetables and others, in addition to its functionl as a protected area.

Study of Nurdin et al, 2014 indicates that the subwatershed of Jeneberang headwater area with a total of 38552 ha located in the headwater of the Bili-bili reservoir have erosion and landslides problems as an indicator of failure in managing the natural resources that have a public benefit. The AVSWAT2000analysis indicated area of land with erosion rate class V (> 480 tonnes / ha / yr) reached 3390.21 ha $(8.79 \%$ of the subwatershed). In Addition, 5826.98 ha was classified as high level of vulnerability / critical land degradation $(15.11 \%)$ dominated in the area of farm / field, and area with vulnerability to landslides was 9819.36 ha $(25.47 \%)$ at slopes of $26-45 \%$ and $46-65 \%$.

Vegetables mostly grown in the headwaters area with generally lacking in the implementation of soil conservation techniques in the land management results in decline soil fertility, disturbed hydrological balance, the water source dries up, the availability of irrigation water is reduced, and an increase in the frequency and size of floods. The longer these problems will lead to a decrease in soil productivity (Kurnia et al. 2004). Serious attention is necessary to avoid the development of agriculture and natural disasters. 


\section{International Journal of Science and Research (IJSR) \\ ISSN (Online): 2319-7064}

Index Copernicus Value (2015): 78.96 | Impact Factor (2015): 6.391

The study aims to evaluate and seek alternative proper soil conservation techniques in controlling erosion and increase land productivity in potato planting area in the headwaters of Jeneberangwatersheds.

\section{Methodology}

The experiment was conducted from February to June 2016 in the area of PT Bunga Indah Malino, Kampung Beru Village, Pattapang Subdistrict, Tinggi Mocong District of Gowa Regency. Four cropping models used as treatments were (1) control, the cultivation practiced by farmers to plant potatoes on planting in the direction of the slope (KTA-1), (2) planting potatoes on the embankment across the slope (KTA-2), (3) planting potatoes on the bed across the slope with two lines of plants (KTA-3) and (4) growing potatoes on the bed across the slope with a trench in every 5 meters (KTA-4). A randomized block design was set using 3 replications with plot size width of $4 \mathrm{~m}$ and a length of $22 \mathrm{~m}$ resulted in 12 experimental plots. To observe erosion and runoff, each plot is equipped with catchment basins. The erosion plots made of rubber sheeting that is embedded as deep as $30 \mathrm{~cm}$ and $20 \mathrm{~cm}$ remain afloat on the surface, to limit any erosion plot. Indicator plant used was potato (Solanumtuberosum L.) with a base fertilizer $200 \mathrm{~kg} \mathrm{Nha}^{-1}$, $250 \mathrm{~kg} \mathrm{P}_{2} \mathrm{O}_{5} \mathrm{ha}^{-1}, 200 \mathrm{~kg} \mathrm{~K}_{2} \mathrm{O} \mathrm{ha}^{-1}$ as well as manure $10 \mathrm{tha}$ 1 . Parameters observed were the rate of erosion and potato production in each plot.

\section{Result and Discussion}

\section{a) Result}

\section{1) Erosion}

Analysis of variance shows that treatment of various cropping models had significant effect on the erosion values. Further test using LSD 0.01 showed in Table 1 indicates that planting in direction of slopes resulted in highest erosion level averagely $27 \mathrm{~kg} \cdot \mathrm{plot}^{-1}$ and is not significantly differed from treatment of planting across the slope (contour farming) with two lines of plants erosion with erosion level of $22.3 \mathrm{~kg} \cdot \mathrm{plot}^{-1}$. Erosion in the two cropping models were significantly higher than the other two models, planting across the slope $\left(0.30 \mathrm{~kg} \cdot \mathrm{plot}^{-1}\right)$ and planting across the slope with trench $\left(0.27 \mathrm{~kg} \cdot \mathrm{plot}^{-1}\right)$.

Table 1: Average Level of Erosion ( $\mathrm{kg} / \mathrm{plot})$ at different cropping models

\begin{tabular}{|c|c|c|}
\hline Treatment / conservation techniques & Average & LSD $_{0.01}$ \\
\hline $\begin{array}{c}\text { Planting in the direction of Slope } \\
\text { (KTA1) }\end{array}$ & $27,00^{\mathrm{a}}$ & \\
\cline { 1 - 2 } $\begin{array}{c}\text { Planting across slope with two lines of } \\
\text { plants (KTA3) }\end{array}$ & $22,33^{\mathrm{b}}$ & \\
\cline { 1 - 2 } Planting across the slope (KTA2) & $0,30^{\mathrm{c}}$ & \\
\cline { 1 - 2 } $\begin{array}{c}\text { Plating across the slope + trench } \\
\text { (KTA4) }\end{array}$ & $0,27^{\mathrm{c}}$ & \\
\hline
\end{tabular}

Note: Values followed by same letter are not significantly different at $\mathrm{LSD}_{0.01}$

\section{2) Production per Plot}

Analysis of variance on production per plot parameter shows that cropping models treatments implemented in the study area had significant impact on the potato production. LSD at $\mathrm{p}<0.05$ results showed in Table 2 indicate that planting across the slope model with two lines of plant gave the highest yield of the potato i.e. $108 \mathrm{~kg} . \mathrm{plot}^{-1}$ and significantly differed from other three cropping models of planting in the direction of the slope, planting across the slope and planting across the slope with trench.

Table 2: The average yield of potatoes $\left(\mathrm{kg}_{\mathrm{g}} \mathrm{plot}^{-1}\right)$ in various models of planting

\begin{tabular}{|c|c|c|}
\hline Treatment / conservation techniques & Average & $L^{2} D_{0.05}$ \\
\hline $\begin{array}{c}\text { Planting in the direction of Slope } \\
\text { (KTA1) }\end{array}$ & $108,00^{\mathrm{a}}$ & \\
\cline { 1 - 2 } $\begin{array}{c}\text { Planting across slope with two lines of } \\
\text { plants (KTA3) }\end{array}$ & $96,00^{\mathrm{b}}$ & \\
\cline { 1 - 2 } Planting across the slope (KTA2) & $87,33^{\mathrm{b}}$ & \\
\cline { 1 - 2 } $\begin{array}{c}\text { Plating across the slope + trench } \\
\text { (KTA4) }\end{array}$ & $87,00^{\mathrm{b}}$ & \\
\hline
\end{tabular}

Note: Values followed by same letter are not significantly different at $\mathrm{LSD}_{0.05}$

\section{b) Discussion}

\section{1) Erosion}

The distribution of rainfall is closely related to the incidence of erosion and runoff, the magnitude of the erosion effect on the design of soil conservation techniques applied in a crop area. Soil conservation techniques were tested in this study affect the amount of erosion that occurred (Table 1).

Soil conservation techniques tested substantially reduce erosion. The erosion rate resulted from conservation technique of planting across the slope with trench wasat the lowest $\left(0.27 \mathrm{~kg} \cdot \mathrm{plot}^{-1}\right)$. This is because theconservation technique that allow the plants planted across the slope preventrunoff as the precipitation that falls on the planting area was blocked by the potato beds and directly being infiltrated into the soil. Had there been runoff occurs, then the water and eroded soil will be accommodated on the existing trench. Therefore, the rate of erosion can be minimized compared to the other treatments. Likewise, the conservation technique of planting across the slope with erosion rate of $0.30 \mathrm{~kg} \cdot \mathrm{plot}^{-1}$ was not significantly different with conservation techniques across the slope with trench This is because the beds that cut the slopes will minimize the rate of runoff and erosion rates to a quite low level.

These results are consistent with research conducted by Barorah and Utami (2001). Implementation of soil conservation was able to reduce runoff and erosionon the potato farm. This is because contourparallel ridges are capable to function as a small dam held their water and provide the opportunity for water to infiltrate into the soil, thereby inhibiting surface flow which in turn also decreases erosion. This function will be more effective on the ground that has a high infiltration capacity as the land Andosol in the Dieng Plateau.

The practice of planting in the direction of the slope is applied by the local farmers generally in the location showed the greatest erosion rate of $27 \mathrm{~kg} \cdot \mathrm{plot}^{-1}$, not significantly different from conservation techniques with 2 lanes of plant model that showed erosion rate of $22.33 \mathrm{~kg}$.plot ${ }^{-1}$. This indicates that conservation techniques performed by potato

\section{Volume 6 Issue 1, January 2017 www.ijsr.net}




\section{International Journal of Science and Research (IJSR) \\ ISSN (Online): 2319-7064}

Index Copernicus Value (2015): 78.96 | Impact Factor (2015): 6.391

farmers have not environmentally friendly, because it gives a fairly high rate of erosion.

Kurnia and Suganda (1999) in Haryati et al. (2011) reported that in generally, vegetable farmers conducted their farming on beds or ridges in the direction of the slope. Otherwise, the ridges are made in the areas of existing bench terraces with the direction of the direction of the slope. The application of conservation techniques in the direction of the slope causes erosion which happens quite high, such as on the ground Andisol Cipanas reached 61.3 to 65.1 t.ha-1 (Suganda et al., 1999) and on the ground Inceptisol Campaka of 32.9 to 43.4 t.ha-1 (Erfandi et al., 2002).

Suganda et al. (1997) and Suganda et al. (1999) in Erfandi et al.(2002) proved that the lowest amount of erosion on the bed in direction of the slope are 10.7 to 40.5 tha $^{-1}$ year $^{-1}$ and $91.1 \mathrm{t} \mathrm{ha}^{-1}$ in Andisol and Inceptisol, respectively. In Inceptisol Cempaka, the amount of erosion on the contour bed of 2.3 to 2.4 tha $^{-1}$ was much smaller than the erosion of the beds in the direction of the slope along the 5 meter cut by terrace ridges that reached10.6 to $15.0 \mathrm{t} \mathrm{ha}^{-1}$.

\section{2) Production per Plot}

The conservation technique of planting across the slope gave the highest production of $108 \mathrm{~kg} \mathrm{plot}^{-1}$ compared to the treatment of other conservation techniques. On the other hand, treatment of soil conservation techniques planting in the direction of the slope gave the lowest production number that is equal to $87 \mathrm{~kg} \mathrm{plot}^{-1}$. This is mainly due to the beds madewere wider compared to potatoes planting seedbed in the other models, causing better and more porous growingmedia for potato tuber growth and development than in the other treatments. Therefore, the potato production is greater and more in number compared to the other treatments.

The results of the potato crop land with contour beds and beds in the direction of the slope with ridge terrace every 4.5 to $5.0 \mathrm{~m}$ was not significantly different to the production of potato with nosoil conservation techniques. But in the longterm these two conservation techniques are estimated able to repair and improve productivity of vegetable farms because of low soil erosion rate, thus ensuring the sustainability of land productivity.

\section{Conclusion}

1) Model of conservation techniques have very significant effect on the rate of erosion. The highest erosion rates occurring on lands with cropping planting in direction of the slope (applied model bythe local potato farmers) when compared to other models of planting.

2) Production of potatoes is highest in the land with cropping model of beds planting across the slope with two lines of plants when compared with other treatments.

\section{References}

[1] Arsyad, S. 2010. Soil and Water Conservation. IPB Press, Kampus IPB Taman Kencana Bogor.
[2] BPS. 2010. Indonesian Statistics. Agriculture and Mining, Horticulture, PertaniandanPertambangan, Hortikultura, Harvested Area, Production and Productivity Chips, Year 2009-2012.

[3] Erfandi, D., UndangKurnia and O. Sopandi. 2002. Erosion control and changes in physical properties of soil on sloping vegetables land. P. 277-286 in Proceedings of the National Seminar on Management of Land Resources and Fertilizers. Book II. Centre for Research and Development of Soil and Agroklimat.Bogor 2002.

[4] Haryati et al, 2011. Alternative Soil Conservation Techniques for Planting Cabbage. Research Agency for Agricultural Research in Soil Research Institute, Jl. TentaraPelajarNo. 12, Bogor 16114

[5] Nurdin, dkk. 2014. Study on Recovery of Watershed Function Based on Criticality Land Level and Potential sliding. Water Engineering Journal, Volume 5, Number 1, May 2014, pp 29-41. Master Program in Water Engineering Brawijaya University in Malang East Java Indonesia.

[6] Saida et al, 2011. Journal of Mathematics, Science, and Technology, Volume 12 Number 2, September 2011, 101-112 Sinukaban, N. 1990. Influence of conservation tillage and straw mulching on crop and nutrient erosion. Preaching Research Soil and Fertilizer, (9): 32-38.

[7] Saida, 2011.Horticultural Crops Development ModelBased Agroecology On sloping land in the watershed upstream Jeneberang.Disertasi.

[8] Seta,AnantaKusuma 1987.KonservasiSumberdaya Tanah dan Air. Jakarta: KalamMulia.

[9] Suganda, H., M. S. Djunaedi, D. Santosoand S. Sukmana. 1997. Effect of erosion control methods against runoff, soil eroded and vegetable production in Andisols. Journal of Soil and Climate. (15): 38-50. Suganda, H., H. Kusnadi and Legal Kurnia. 1999. Effect of direction rows and beds in erosion control in vegetable production plateau. Journal of Soil and Climate, (17): 55-64.

[10] Barorah, U. danUtami, L. 2001.Effect of Soil Conservation tidakan Against the Flow Surface, erosion, loss of Hara And Earnings In Farm Potatoes And Cabbage. Journal of Human and Environment, Vol. WII, No. 2, August 2001, p. 98-107 Centre for Environmental Studies' GadjahMada University in Yogyakarta, Indonesia.

[11] Kurnia, U. 1996. Study of Land Rehabilitation Methods to Increase Productivity and Preserving Land. Doctoral Dissertation Graduate Program, InstitutPertanian Bogor. Invite Kurnia and H. Suganda. 1999. Soil and water conservation in vegetable production plateau. Journal of Agricultural Research and Development, 18 (2): 68-74.

[12] Kurnia, U. 2000. Application of soil conservation techniques on farmland plateau. It 47-57 in Abdurachman A. et al. (Eds.).Proceedings of the National Workshop Discussion of Watershed Management Research. Bogor, 2-3 September 1999. Soil and Agro-climate Research Center, Bogor. 